\title{
W KWESTII CHARAKTERU PRAWNEGO POSTĘPOWANIA O UDOSTĘPNIENIE INFORMACJI PUBLICZNEJ
}

Prawo dostępu do informacji publicznej ustanowione w art. 61 Konstytucji RP ${ }^{1}$ uznawane jest za publiczne prawo podmiotowe o charakterze politycznym². Prawo to ma zagwarantować transparentność, rzetelność i sprawność działania władzy publicznej poprzez sprawowanie nad nią społecznej (obywatelskiej) kontroli. Dostęp do informacji, a w konsekwencji jawność życia publicznego ma zapobiegać nadużyciom, przeciwdziałać korupcji, poprawiać jakość funkcjonowania administracji publicznej3 ${ }^{3}$. Konstytucja stanowi, że prawo do uzyskania informacji obejmuje w szczególności dostęp do dokumentów oraz wstęp na posiedzenia kolegialnych organów władzy publicznej pochodzących z wyborów powszechnych z możliwością rejestracji dźwięku i obrazu. Określenie trybu udostępniania przedmiotowej informacji zostało przekazane na podstawie art. 61 ust. 4 Konstytucji RP do uregulowania przez ustawodawcę zwykłego ${ }^{4}$.

Prawodawca, realizując delegację konstytucyjną, sprecyzował procedurę udostępniania informacji publicznej $\mathrm{W}$ ustawie $\mathrm{z}$ dnia

* Dr, Katolicki Uniwersytet Lubelski Jana Pawła II; e-mail: maciej.gapski@kul.pl, https:/ / orcid.org/0000-0002-5454-6645.

1 Konstytucja Rzeczypospolitej Polskiej z dnia 2 kwietnia 1997 r., Dz. U. z 1997 r. Nr 78, poz. 483 z późn. zm.

2 Szerzej zob. K. Tomaszewska, Dostęp do informacji publicznej jako kategoria ochrony interesu prawnego jednostki w regulacjach prawa administracyjnego, Warszawa 2015, s. 41-43.

3 W. Sokolewicz, K. Wojtyczek, uwaga 5 do art. 61, w: Konstytucja Rzeczypospolitej Polskiej. Komentarz, t. 2, red. L. Garlicki, M. Zubik, wyd. 2, Warszawa 2016 [wyd. el. LEX] wraz powołaną tam literaturą.

4 W. Sokolewicz, K. Wojtyczek, uwaga 5 do art. 61. 
6 września 2001 r. o dostępie do informacji publicznej ${ }^{5}$. W doktrynie prawa i orzecznictwie sądów administracyjnych istnieją daleko idące rozbieżności co do charakteru prawnego postępowania o udostępnienie informacji publicznej, przede wszystkim w odniesieniu do sytuacji, gdy postępowanie to kończy się decyzją o odmowie udostępnienia informacji lub umorzeniu postępowania ${ }^{6}$. W niektórych wypowiedziach uznaje się owo postępowanie za administracyjne postępowanie jurysdykcyjne, $\mathrm{w}$ innych odmawia się mu takiego charakteru.

W niniejszym opracowaniu przedstawiono, w zakresie uzasadnionym przez jego przedmiot, tryb postępowania w sprawie udostępnienia informacji publicznej, a także zaprezentowano aktualne orzecznictwo sądowoadministracyjne oraz poglądy doktryny na temat charakteru prawnego tego postępowania. Rozważania te zmierzają do ustalenia charakteru prawnego przedmiotowego postępowania w perspektywie podstawowych cech administracyjnego postępowania jurysdykcyjnego.

\section{Postępowanie w sprawie udostępnienia informacji publicznej}

Ustawa o dostępie do informacji publicznej przyznaje prymat bezwnioskowemu udostępnianiu tejże informacji ${ }^{7}$. Rozwiązanie takie ułatwia dostęp do informacji zarówno z punktu widzenia podmiotów zobowiązanych do udzielania informacji publicznej, jak i tych, które chcą

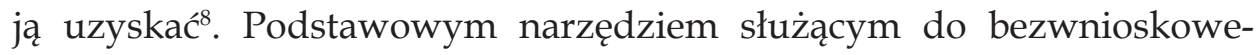

5 Tekst jednolity: Dz. U. z 2019 r. poz. 1429 z późn. zm.

6 Zob. wyrok NSA z dnia 11 kwietnia 2019 r., I OSK 1343/17, LEX nr 2682054; wyrok NSA z dnia 7 marca 2019 r., I OSK 2643/17, LEX nr 2646196; wyrok NSA z dnia 12 czerwca 2015 r., I OSK 1512/14, LEX nr 2089727; wyrok NSA z dnia 4 listopada 2016 r., I OSK 1372/15, LEX nr 2169772; wyrok WSA w Warszawie z dnia 30 stycznia 2019 r., II SA/Wa 1296/18, LEX nr 2653467; wyrok WSA we Wrocławiu z dnia 29 maja 2018 r., IV SAB/Wr 30/18, LEX nr 2507573, a także: T.R. Aleksandrowicz, Komentarz do ustawy o dostepie do informacji publicznej, Warszawa 2008, s. 249; M. Rozbicka-Ostrowska, Decyzja o odmowie udostęnienia informacji publicznej, w: Komentarz do spraw administracyjnych, red. I. Kamińska, J. Matarewicz, M. Rozbicka-Ostrowska, Warszawa 2015 [wyd. el. LEX].

7 Zob. szerzej M. Bernaczyk, Obowiązek bezwnioskowego udostepniania informacji publicznej, Warszawa 2008, s. 150-156.

8 Por. K. Kędzierski, Bezwnioskowy tryb udzielania informacji publicznej, w: Dostęp do informacji publicznej, red. P. Szustakiewicz, Warszawa 2014, s. 123. 
go udostępniania i uzyskiwania informacji jest urzędowy publikator teleinformatyczny - Biuletyn Informacji Publicznej'. Wybrane podmioty publiczne zostały na postawie art. 9a ust. 1 i 2 ustawy o dostępie do informacji publicznej zobowiązane do udostępniania pewnych kategorii informacji publicznych $w$ tzw. centralnym repozytorium powszechnie dostępnym $\mathrm{w}$ sieci teleinformatycznej. Istotne jest, że zgodnie z art. 10 ust. 1 tej ustawy dopiero w przypadku nieudostępnienia informacji w BIP lub centralnym repozytorium informacja publiczna jest udostępniania na wniosek. Tym samym dostęp do informacji publicznej może polegać na czynnościach faktycznych podmiotów zainteresowanych, tj. zapoznawaniu się z przedmiotową informacją w szczególności poprzez wykorzystanie urządzeń elektronicznych oraz sieci internetowej bez konieczności wszczynania jakiegokolwiek postępowania.

Brak bezpośredniego, powszechnego dostępu do informacji publicznej obliguje zainteresowanych do złożenia stosownego wniosku. Podmiot występujący o udostępnienie informacji stosownie do art. 2 ustawy o dostępie do informacji publicznej nie ma obowiązku wykazywania interesu prawnego lub faktycznego, a sam wniosek nie musi przybrać szczególnej formy. W przypadku prowadzenia postępowania wyłącznie na podstawie ustawy o dostępie do informacji publicznej, a więc sytuacji, gdy: podmiot udostępnia informację publiczną, podmiot nie posiada żądanej informacji, podmiot jest niewłaściwy do udostępnienia informacji, żądana informacja nie jest informacją publiczną w rozumieniu ustawy, istnieje odrębny tryb udostępnienia informacji lub też wniosek został skierowany do podmiotu, który nie jest obowiązany do udostępnienia informacji publicznej załatwienie wniosku następuje za pomocą czynności materialno-technicznej ${ }^{10}$. Czynności tego rodzaju wywołują określone skutki prawne poprzez fakty, a nie przez bezpośrednie tworzenie nowej indywidualnej normy porządku prawnego ${ }^{11}$.

9 Dalej: BIP.

10 Zob. wyrok WSA w Gliwicach z dnia 11 kwietnia 2018 r., IV SAB/Gl 28/18, LEX nr 2482383, a także M. Jabłoński, Udostępnianie informacji publicznej w trybie wnioskowym, Wrocław 2014, s. 176-177. Odmiennie T.R. Aleksandrowicz, Komentarz do ustawy..., s. 249. Autor ten twierdzi, że niezależnie od sposobu zakończenia postępowania (udostępnienie informacji, odmowa udostępnienia lub umorzenie postępowania) organy powinny wydać decyzję administracyjną.

11 J. Starościak, Prawne formy działania administracji publicznej, Warszawa 1957, s. 299; szerzej M. Masternak, Czynności materialno-techniczne jako prawna forma działania administracji publicznej, Torun 2018, s. 116-126. 
Jednocześnie ważne jest, że chociaż udostępnienie informacji publicznej należy zakwalifikować do czynności faktycznych organów administracji publicznej, to czynności te podejmowane w sferze praw i wolności obywateli są ściśle regulowane przez przepisy prawa powszechnie obowiązującego i przy ich realizacji nie ma miejsca na swobodę działania organów ${ }^{12}$.

W relacji do ogólnego postępowania administracyjnego o charakterze jurysdykcyjnym, którego celem jest władcza i jednostronna konkretyzacja praw i obowiązków jednostki w drodze decyzji administracyjnej ${ }^{13}$, postępowanie o udostępnienie informacji publicznej zajmuje szczególne miejsce. Postępowanie to służy bowiem urzeczywistnieniu konstytucyjnego prawa do informacji o działalności podmiotów publicznych i nie rozstrzyga się $\mathrm{w}$ nim o indywidualnych prawach i obowiązkach $\mathrm{w}$ drodze aktu administracyjnego. To konstytucyjne zakotwiczenie analizowanego postępowania uzasadnia szczególny tryb udostępniania informacji publicznej, która co do zasady powinna być jawna i powszechnie dostępna. Dlatego też w działaniach organów władzy i innych podmiotów, zmierzających do udostępnienia informacji publicznej, przeważają czynności faktyczne ściśle regulowane przez prawo. W postępowaniach tych udostępnienie informacji publicznej staje się regułą, natomiast odmowa jej udostępnienia lub umorzenie postępowania wyjątkiem ${ }^{14}$. W tych dwóch ostatnich przypadkach podmioty zobowiązane do udostępniania informacji nie mogą zakończyć postępowania za pomocą czynności materialno-technicznej, lecz stosownie do art. 16 ust. 1 i 2 ustawy o dostępie do informacji publicznej zobligowane są wydać decyzję, do której stosuje się przepisy Kodeksu postępowania administracyjnego ${ }^{15}$.

12 Por. A. Błaś, Czynności faktyczne organów administracji publicznej, w: Koncepcja systemu prawa administracyjnego, Zjazd Katedr Prawa Administracyjnego i Postępowania Administracyjnego, Zakopane 23-27 września 2006 r., red. J. Zimmermann, Warszawa 2007, s. 508, 515.

13 Por. Z. Janowicz, Kodeks postępowania administracyjnego. Komentarz, Warszawa-Poznań 1995, s. 22; B. Adamiak, Koncepcja postępowania administracyjnego, w: Prawo procesowe administracyjne, t. 9. System Prawa Administracyjnego, red. R. Hauser, Z. Niewiadomski, A. Wróbel, Warszawa 2010, s. 3; J. Zimmermann, Polska jurysdykcja administracyjna, Warszawa 1996, s. 11-13.

14 Zob. wyrok NSA z dnia 5 lutego 2019 r., I OSK 840/17, LEX nr 2624677.

15 Ustawa z dnia 14 czerwca 1960 r. - Kodeks postępowania administracyjnego, tekst jednolity: Dz. U. z 2020 r. poz. 256 z późn. zm. (dalej: K.p.a.). 


\section{Poglądy doktryny oraz stanowisko sądów administracyjnych dotyczące charakteru prawnego postępowania o udostępnienie informacji publicznej}

W orzecznictwie sądów administracyjnych oraz $\mathrm{w}$ doktrynie prezentowane są co najmniej trzy poglądy dotyczące charakteru prawnego postępowania o udostępnienie informacji publicznej. W myśl pierwszego $\mathrm{z}$ nich przedmiotowe postępowanie ma charakter jurysdykcyjny niezależnie od tego, czy organ udziela informacji, czy też odmawia jej udostępnienia. Stanowisko takie przedstawił T.R. Aleksandrowicz, który wskazuje, że organ zarówno w sytuacji, gdy udostępnia informację publiczną, jak i odmawia jej udostępnienia powinien wydać decyzję administracyjną, konkretyzującą sytuację prawną indywidualnie oznaczonego adresata ${ }^{16}$. Stanowisko to nie znalazło jednak szerszej akceptacji w teorii oraz praktyce stosowania ustawy o dostępie do informacji publicznej ${ }^{17}$.

Zdaniem J. Borkowskiego natomiast podmiot ubiegający się o dostęp do informacji publicznej nie ma obowiązku wykazania swojego interesu prawnego lub faktycznego, jednakże staje się stroną postępowania administracyjnego, gdy zaistnieją podstawy prawne do odmowy spełnienia jego żądania w drodze decyzji administracyjnej ${ }^{18}$. Wówczas też sprawa dostępu do informacji publicznej przekształca się w indywidualną sprawę administracyjną w rozumieniu art. 1 pkt 1 K.p.a., której przedmiotem jest stwierdzenie istnienia przeszkód prawnych w udostępnieniu informacji ${ }^{19}$.

W orzecznictwie sądów administracyjnych najczęściej prezentowane jest podobne stanowisko zakładające, że jurysdykcyjne postępowanie administracyjne aktualizuje się tylko w przypadku wydania decyzji o odmowie udostępnienia informacji lub umorzenia postępowania. Naczelny Sąd Administracyjny w wyroku z dnia 11 kwietnia 2019 r. ${ }^{20}$ stwierdził,

16 T.R. Aleksandrowicz, Komentarz do ustawy..., s. 249.

17 Zob. I. Kamińska, M. Rozbicka-Ostrowska, Ustawa o dostępie do informacji publicznej. Komentarz, Warszawa 2016, s. 313-314 wraz z powołaną tam literaturą.

18 J. Borkowski, System regulacji prawa procesowego administracyjnego, w: Prawo procesowe..., s. 84 .

19 Tamże. Zob. podobnie S. Szuster, uwaga 1 do art. 16, w: M. Kłaczyński, S. Szuster, Dostęp do informacji publicznej. Komentarz, Warszawa 2003 [wyd. el. LEX].

20 Wyrok NSA z dnia 11 kwietnia 2019 r., I OSK 1343/17, LEX nr 2682054, podobnie wyrok WSA w Poznaniu z dnia 16 stycznia 2019 r., IV SA/Po 817/17, LEX nr 2624596. 
że: „Zgodnie z art. 16 ust. 2 ustawy o dostępie do informacji publicznej do decyzji odmownej oraz o umorzeniu postępowania stosuje się przepisy K.p.a. Oznacza to, że kodeks ten ma zastosowanie do całego procesu wydawania decyzji, czyli chodzi o przepisy regulujące procedurę, która kończy się wydaniem decyzji, jak i te, które normują dalsze postępowanie w sprawie zakończonej wydaniem decyzji. Nie ulega zatem wątpliwości, że postępowanie w sprawie odmowy udostępnienia informacji publicznej jest sformalizowanym, jurysdykcyjnym postępowaniem administracyjnym, które może się toczyć w dwóch instancjach". W powyższym wyroku NSA nie uzasadnił szerzej swego stanowiska - poza powołaniem się na formalny charakter procedury oraz konieczność stosowania K.p.a. w przypadku odmowy udostępnienia informacji publicznej.

W orzecznictwie NSA można jednak odnaleźć także odmienny pogląd dotyczący charakteru prawnego analizowanego postępowania. Sąd ten w wyroku z dnia 4 listopada 2016 r. ${ }^{21}$ wyjaśnił, że postępowanie $\mathrm{w}$ sprawie udostępnienia informacji publicznej nie ma charakteru postępowania jurysdykcyjnego, a w konsekwencji decyzja o odmowie udostępnienia informacji publicznej - jako niewydawana w indywidulanej sprawie administracyjnej w rozumieniu art. 1 pkt 1 K.p.a. - nie jest aktem administracyjnym w materialnym znaczeniu. Decyzja wydawana na podstawie art. 16 ust. 2 ustawy o dostępie do informacji publicznej stanowi wyłącznie jedną z form zakończenia postępowania i ma przede wszystkim walor gwarancyjny, pozwala adresatowi decyzji składać środki prawne oraz skargi do sądu administracyjnego. NSA stwierdził, że przedmiotowa decyzja jest alternatywą dla czynności udostępnienia informacji publicznej i ma charakter odmowy uwzględnienia wniosku inicjującego sprawę o udostępnianie informacji publicznej, a więc nie rozstrzyga sprawy administracyjnej co do istoty w całości lub części w znaczeniu, jakie wynika z art. $104 \S 2$ K.p.a. Ustawa o dostępie do informacji publicznej w ograniczonym zakresie odwołuje się do K.p.a. i ma w stosunku do regulacji kodeksowych charakter lex specialis. Wobec odrębnego uregulowania w ustawie materialnych i formalnych kwestii udostępniania informacji, w tym zakresu podmiotowego oraz szczególnego sposobu działania organów, należy zdaniem sądu uznać, że w sprawach tych nie stosuje się art. 28 K.p.a. Stroną postępowania o udostępnienie informacji publicznej jest zatem wyłącznie wnioskodawca, co wynika z art. 2 ust. 1,

${ }^{21}$ Wyrok NSA z dnia 4 listopada 2016 r., I OSK 1372/15, LEX nr 2169772. 
art. 10 ust. 1 oraz art. 14 ust. 1 ustawy o dostępie do informacji publicznej interpretowanych w kontekście charakteru prawnego postępowania w sprawie udostępnienie tego rodzaju informacji. NSA wyjaśnił również, że gdyby sprawa o udostępnienie informacji publicznej była indywidualną sprawą administracyjną, $\mathrm{w}$ rozumieniu art. 1 pkt 1 K.p.a., rozstrzyganą $\mathrm{w}$ drodze indywidualnego aktu administracyjnego, tj. w drodze decyzji administracyjnej, o jakiej mowa w art. 104 K.p.a., to zbędna byłaby regulacja art. 21 ustawy o dostępie do informacji publicznej gwarantująca możliwość zaskarżania decyzji wydanych w ramach tego postępowania do sądu administracyjnego.

Część przedstawicieli doktryny także odmawia postępowaniu o udostępnienie informacji publicznej charakteru jurysdykcyjnego ${ }^{22}$. Uzasadniając to stanowisko, wskazuje się, że w przypadku odmowy udostępnienia informacji lub umorzenia postępowania rozstrzygnięcie zapada wprawdzie $\mathrm{w}$ formie decyzji, a więc $\mathrm{w}$ formie zarezerwowanej dla postępowania jurysdykcyjnego, to jednak zabieg ten ma wyłącznie charakter gwarancyjny. Dzięki skorzystaniu z takiego rozwiązania podmiot żądający udostępnienia informacji w przypadku wydania decyzji odmownej lub umarzającej może skorzystać z postępowania odwoławczego oraz zaskarżyć rozstrzygniecie do sądu administracyjnego ${ }^{23}$.

\section{Charakter prawny postępowania o udostępnienie informacji publicznej}

W doktrynie prawa administracyjnego podkreśla się, że podstawowym celem postępowania jurysdykcyjnego jest uzyskanie regulującej stosunek prawny normy konkretnej stanowiącej jego wynik, a jego najistotniejszymi elementami są: strona, interes prawny oraz decyzja administracyjna ${ }^{24}$.

22 A. Piskorz-Ryń, Zasady udostęniania informacji publicznej, w: Dostęp do informacji publicznej na wniosek w praktyce jednostek samorzadu terytorialnego, red. J. Wyporska-Frankiewicz, Warszawa 2019, s. 58. Zob. też J. Drachal, Zagadnienia sądowej ochrony prawa do informacji, Zeszyty Naukowe Sądownictwa Administracyjnego 2010, nr 5-6, s. 108-109.

${ }^{23}$ Por. S. Szuster, uwaga 3 do art. 10, w: Dostęp do informacji publicznej. Komentarz.

24 M. Zimmermann, Z rozważań nad postępowaniem jurysdykcyjnym i pojęciem strony w Kodeksie postępowania administracyjnego, w: Księga pamiątkowa ku czci Kamila Stefki, Warszawa-Wrocław 1967, s. 433-434. 
Przedmiotem postępowania jurysdykcyjnego są sprawy indywidualne rozpatrywane decyzją administracyjną ${ }^{25}$. W sprawie administracyjnej dokonuje się konkretyzacji indywidualnych praw lub obowiązków przez podmioty (organy), które są do tego prawnie umocowane i dokonują tego w normatywnie przypisanej formie decyzji stosowania prawa. Organ powołany będzie mógł wydać w sprawie indywidualnej akt administracyjny (decyzję) wyłącznie w sytuacji, gdy z materialnych przepisów prawa administracyjnego imiennie oznaczone osoby wywodzą swój interes prawny lub obowiązek ${ }^{26}$. Akt stosowania prawa administracyjnego - akt jurysdykcyjny - ma najczęściej charakter konstytutywny, gdyż nie potwierdza istnienia prawa lub obowiązku, ale go tworzy, w ślad za ogólną i abstrakcyjną normą prawa materialnego ${ }^{27}$. Akt jurysdykcji nie zawsze ustala nowe prawa i obowiązki, może bowiem również modyfikować lub uchylać poprzednio orzeczone uprawniania lub obowiązki, a także odmawiać przyznania uprawnienia lub nie nakładać obowiązku (decyzje negatywne $)^{28}$.

Typowym postępowaniem jurysdykcyjnym jest ogólne postępowanie administracyjne regulowane przepisami K.p.a. Do tego rodzaju postępowań zalicza się również postępowanie podatkowe oraz postępowanie przed polskimi przedstawicielstwami dyplomatycznymi i konsularny$\mathrm{mi}^{29}$. Ogólne postępowanie administracyjne uregulowane w art. 1 pkt 1 i 2 K.p.a. ma bezpośrednio na celu - według A. Wróbla - wiążące ustalenie konsekwencji norm prawa materialnego, w odniesieniu do konkretnie oznaczonego adresata w sprawie indywidualnej, przez organ administracji publicznej w formie decyzji ${ }^{30}$.

Mając na uwadze zaprezentowane powyżej poglądy dotyczące charakteru postępowania o udostępnienie informacji publicznej oraz wskazane cechy postępowania jurysdykcyjnego, zasadne jest uznanie, że analizowane postępowanie nie ma charakteru jurysdykcyjnego i to niezależnie

25 J. Borkowski, w: B. Adamiak, J. Borkowski, Kodeks postępowania administracyjnego. Komentarz, Warszawa 2014, s. 12.

26 Tamże.

27 J. Zimmermann, Polska jurysdykcja..., s. 7.

28 Tamże, s. 26.

29 R. Kędziora, Ogólne postępowanie administracyjne, Warszawa 2015, s. 12.

30 A. Wróbel, w: A. Wróbel, M. Jaśkowska, Kodeks postępowania administracyjnego. Komentarz, Warszawa 2016, s. 34. 
od tego, w jakiej formie procesowej się kończy - czynności materialno-technicznej czy decyzji.

Uzasadniając powyższe stanowisko, warto odnieść się do strony podmiotowej postępowania o udostępnienie informacji publicznej, a także samego pojęcia informacji publicznej. Ustawa o dostępie do informacji publicznej wprowadza szeroki, niemal nieograniczony zakres podmiotów uprawnionych do wnioskowania o udostępnienie przedmiotowej informacji. $\mathrm{Z}$ art. 2 ust. 1 ustawy o dostępie do informacji publicznej wynika, że każdemu przysługuje prawo dostępu do informacji publicznej, co pozwala na uznanie, że wniosek może pochodzić od osób fizycznych i prawnych, a także jednostek organizacyjnych nieposiadających osobowości prawnej $^{31}$. W doktrynie podkreśla się, że osoby fizyczne występujące z wnioskiem o informację publiczną powinny być pełnoletnie i nieubezwłasnowolnione ${ }^{32}$, a osoby prawne i jednostki organizacyjne reprezentowane przez właściwe organy ${ }^{33}$.

Do udostępnienia informacji publicznej, stosownie do art. 4 ust. 1 ustawy o dostępie do informacji publicznej, obowiązane są władze publiczne oraz inne podmioty wykonujące zadania publiczne, do których przykładowo zaliczono organy władzy publicznej, samorządu zawodowego i gospodarczego, czy podmioty reprezentujące Skarb Państwa. Ustawodawca szczegółowo nie określił podmiotów zobowiązanych do udostępnienia informacji publicznej i nie ograniczył ich jedynie do podmiotów publicznych. W orzecznictwie sądów administracyjnych wskazuje się, że każdy podmiot gospodarujący pieniędzmi publicznymi lub wykonujący funkcje publiczne, niezależnie od formy organizacyjnej czy właściciela, zobowiązany jest do udzielenia informacji publicznej w zakresie, $w$ jakim korzysta ze środków lub wykonuje zadania publiczne ${ }^{34}$. Obowiązek udostępnienia informacji spoczywa więc nie tylko na organach administracji rządowej i samorządowej, ale również na innych podmiotach publicznych

31 M. Jaśkowska, Dostęp do informacji publicznych w świetle orzecznictwa Naczelnego Sądu Administracyjnego, Torun 2002, s. 41.

32 Odnośnie do możliwości udostępniania informacji publicznej dzieciom zob. M. Bernaczyk, Prawo do informacji publicznej w Polsce i na świecie, Warszawa 2014, s. 288-289.

33 P. Szustakiewicz, w: M. Bidziński, M. Chmaj, P. Szustakiewicz, Ustawa o dostępie do informacji publicznej. Komentarz, Warszawa 2015, s. 22-24.

34 Zob. P. Szustakiewicz, Orzecznictwo Naczelnego Sąu Administracyjnego z lat 2015-2018 w sprawach dotyczacych informacji publicznej, Przegląd Prawa Publicznego 2019, nr 7-8, s. 13-14. 
i prywatnych, w tym przedsiębiorstwach, spółkach, związkach zawodowych lub sportowych ${ }^{35}$. Należy podkreślić, że ustawa o dostępie do informacji publicznej nie utożsamia pojęcia organu zobowiązanego do udostępnienia informacji publicznej z organem administracji publicznej w znaczeniu przyjętym w K.p.a. i znacząco rozszerza katalog podmiotów obowiązanych do udostępnienia informacji publicznej ${ }^{36}$. Istotne jest ponadto, że podmiot występujący o udostępnienie informacji, zgodnie $\mathrm{z}$ art. 2 ust. 2 ustawy o dostępie do informacji publicznej nie musi legitymować się interesem prawnym, ani nawet faktycznym. Odrębne niż w regulacjach kodeksowych ukształtowanie zakresu podmiotowego oraz roli interesu prawnego z punktu widzenia legitymacji do żądania informacji świadczy o daleko idącej specyfice postępowania o udostępnienie informacji publicznej oraz o jego odmienności w stosunku od ogólnego postępowania administracyjnego.

Odnosząc się do zakresu przedmiotowego pojęcia informacja publiczna, konieczne jest przywołanie art. 1 ust. 1 in principio ustawy o dostępie do informacji publicznej, gdzie zdefiniowano, że każda informacja o sprawach publicznych stanowi informację publiczną. Szeroka, a w istocie niedookreślona definicja ustawowa informacji publicznej nakazuje zaliczenie do tej kategorii rozległego zakresu informacji ${ }^{37}$. Doktryna oraz orzecznictwo wskazują, że pojęcie to obejmuje w zasadzie każdą wiadomość wytworzoną przez władze publiczne, osoby pełniące funkcje publiczne, a także inne podmioty, które tę władzę realizują bądź gospodarują w zakresie swoich kompetencji majątkiem komunalnym lub majątkiem Skarbu Państwa ${ }^{38}$. Zawarty w art. 6 ustawy o dostępie do informacji publicznej katalog informacji, które zdaniem ustawodawcy są informacjami publicznymi, nie jest zamknięty, stanowi jedynie przykładowe zestawienie. Zabieg taki należy uznać za przemyślany i uzasadniony ${ }^{39}$, gdyż trudne jest stworzenie uniwersalnej definicji informacji publicznej, a z pewnością niemożliwe kazuistyczne skatalogowanie całego jej przedmiotu. Szeroka definicja informacji

35 Tamże.

${ }^{36}$ Zob. I. Kamińska, M. Rozbicka-Ostrowska, Ustawa o dostępie..., s. 91.

37 Zob. P. Szustakiewicz, Zakres przedmiotowy informacji publicznej. Glosa aprobujaca do wyroku Naczelnego Sądu Administracyjnego z 13 lutego 2019 r. (I OSK 315/17), Samorząd Terytorialny 2019, nr 11, s. 78.

38 Tak w odniesieniu do orzecznictwa NSA J. Drachal, Zagadnienia sądowej ochrony..., s. 101.

39 P. Szustakiewicz, Zakres przedmiotowy..., s. 79. 
publicznej pozwala na nieskrępowaną, społeczną kontrolę podmiotów wykonujących funkcje publiczne bądź dysponujących majątkiem publicznym, a równocześnie umożliwia dostosowanie jej znaczenia do zmieniających się stosunków społecznych, gospodarczych oraz technicznych. Równocześnie istotną rolę dla dookreślenia tego pojęcia i uchwycenia jego dynamicznych przeobrażeń odgrywają sądy administracyjne, czuwające nad prawidłowością stosowania ustawy o dostępie do informacji publicznej przez podmioty zobowiązane do udostępniania tych informacji ${ }^{40}$.

Należy zauważyć, iż w podstawowym zakresie przedmiotem postępowania prowadzonego na podstawie ustawy o dostępie do informacji publicznej jest udostępnienie informacji publicznej, a nie rozstrzyganie o prawach i obowiązkach indywidualnie oznaczonego podmiotu występującego z żądaniem jej udostępnienia. Dlatego też w odniesieniu do tych sytuacji, gdy postępowanie o udostępnienie informacji publicznej zakończone jest czynnością materialno-techniczną, przede wszystkim w postaci udostępnienia informacji, nie ma żadnych podstaw dogmatycznych ani teoretycznych, aby uznać je za postępowanie jurysdykcyjne. Wskazana czynność nie tworzy bowiem indywidualnej normy stosowania prawa i tym samym nie rozstrzyga o indywidualnych uprawieniach i obowiązkach. Za takie „indywidualnie uprawnienie" nie możne być uznane konstytucyjne prawo do informacji przysługujące każdemu bez wyjątku. Ponadto w postępowaniu o udostępnienie informacji publicznej bez znaczenia jest istnienie interesu prawnego lub nawet faktycznego po stronie podmiotu żądającego przekazania mu informacji publicznej ${ }^{41}$. W orzecznictwie i literaturze przyjmuje się obecnie jednolicie, że postępowanie kończące się udostępnieniem informacji publicznej nie ma charakteru jurysdykcyjnego ${ }^{42}$.

Należy dodatkowo zauważyć, że w prawie administracyjnym występują dość licznie postępowania, które kończy czynność materialno-techniczna w przypadku pozytywnego rozpatrzenia wniosku albo decyzja administracyjna w przypadku negatywnego rozstrzygnięcia żądania lub konieczności nałożenia obowiązku administracyjnoprawnego. Orzeczenia wydawane $\mathrm{w}$ tego typu postępowaniach mogą być uznane za akty

40 Zob. P. Szustakiewicz, Orzecznictwo..., s. 11-12, a także M. Jaśkowska, Dostęp do informacji publicznej w orzecznictwie sądów administracyjnych (wybrane problemy), Zeszyty Naukowe Sądownictwa Administracyjnego 2014, nr 1, s. 9-12.

${ }^{41}$ Zob. art. 2 ust. 1 i 2 ustawy o dostępie do informacji publicznej.

${ }^{42}$ I. Kamińska, M. Rozbicka-Ostrowska, Ustawa o dostępie..., s. 266 oraz podana tam literatura i orzecznictwo. 
jurysdykcyjne wyłącznie $\mathrm{w}$ przypadku, gdy władczo rozstrzygają o interesie prawnym wynikającym z materialnego prawa administracyjnego konkretnie oznaczonych podmiotów, czyli stanowią indywidualne akty stosowania prawa. Przykładem tego typu postępowania jest postępowanie dotyczące prawa do świadczenia wychowawczego, regulowane ustawą o pomocy państwa $\mathrm{w}$ wychowaniu dzieci ${ }^{43}$. Przyznawanie tych świadczeń nie wymaga wydania decyzji (zgodnie z art. 13a ust. 1), natomiast odmowa przyznania świadczenia wychowawczego, uchylenie lub zmiana prawa do świadczenia wychowawczego oraz rozstrzygnięcie w sprawie nienależnie pobranego świadczenia wychowawczego następuje na podstawie decyzji administracyjnej ${ }^{44}$. Przyznając świadczenie wychowawcze, właściwy organ jest obowiązany do poinformowania wnioskodawcy o tym fakcie na adres poczty elektronicznej, jednakże nieodebranie informacji nie stanowi przeszkody do wypłaty świadczenia. Wydając decyzję odmawiającą przyznania świadczenia, uchylającą lub zmieniającą prawo do świadczenia, a także w sprawie nienależnie pobranych świadczeń, organy stosują - poza ustawą o pomocy państwa w wychowaniu dzieci także K.p.a. (art. 28 powołanej ustawy). Ze względu na to, że wskazane decyzje rozstrzygają o prawie do świadczenia, modyfikują jego zakres albo nakładają obowiązek jego zwrotu, należy je zakwalifikować do indywidualnych aktów stosowania prawa, a zatem postępowanie prowadzące do ich wydania ma charakter jurysdykcyjny.

Za takiego rodzaju postępowanie nie można jednak uznać postępowania w przedmiocie odmowy udostępnienia informacji publicznej lub umorzenia postępowania (art. 16 ustawy o dostępie do informacji publicznej), gdyż nie rozstrzyga się w nim o uprawnieniach lub obowiązkach (interesie prawnym) jakiegokolwiek podmiotu, w tym żądającego dostępu do informacji publicznej.

Jak wyjaśniono powyżej, w postępowaniu o udostępnienie informacji publicznej nie bada się istnienia interesu prawnego lub faktycznego podmiotu żądającego udostępnienia informacji publicznej i nie ma on

43 Ustawa z dnia 11 lutego 2016 r. o pomocy państwa w wychowaniu dzieci, tekst jednolity: Dz. U. z 2019 r. poz. 2407.

44 Przykładem takiego postępowania jest również postępowanie o wydanie odpisu aktu stanu cywilnego, które w zakresie pozytywnego załatwienia wniosku, czyli wydania aktu, kończy się czynnością materialno-techniczną, a w sytuacji odmowy wydania aktu decyzją administracyjną - art. 2 pkt 8 w zw. z art. 45 ustawy z dnia 28 listopada 2014 r. Prawo o aktach stanu cywilnego, tekst jednolity: Dz. U. z 2020 r. poz. 463 z późn. zm. 
znaczenia dla trybu działania organu zobowiązanego do udzielenia informacji publicznej. Wskazuje się jednak, że konkretne żądanie udzielenia takiej informacji musi podlegać ocenie przez organ, który bada, czy dotyczy ono informacji publicznych ważnych i interesujących dla ogółu, a podmiot występujący o taką informację powinien mieć obiektywny, a nie subiektywny interes $\mathrm{w}$ jej uzyskaniu ${ }^{45}$. Rozwijając to twierdzenie, należy przytoczyć wypowiedź J. Drachala, który podkreśla, że prawo do informacji nigdy nie było gwarantem ochrony jednostkowych (prywatnych) interesów obywateli i innych podmiotów prawa, lecz wiązało się z tzw. interesem ogólnym - dobrem publicznym ${ }^{46}$. To właśnie ów interes ogólny (publiczny), a nie indywidualny jest podstawą do występowania z żądaniem dostępu do informacji publicznej ${ }^{47}$. Niewykluczone jest przy tym, że wnioskujący o udostępnienie informacji będzie dysponował indywidualnym interesem prawnym lub faktycznym, jednakże okoliczność ta pozostaje bez wpływu na pozytywne lub negatywne rozpatrzenie żądania ${ }^{48}$. Podmiot wnioskujący może uzyskać dostęp wyłącznie do informacji publicznych, których jawność z uwagi na dobro publiczne przewidują obowiązujące regulacje prawne ${ }^{49}$. Tym samym obiektywy interes prawny $\mathrm{w}$ postępowaniu o udostępnienie informacji publicznej przejawia się w tym, że każdy wnioskujący o konkretną, tożsamą informację może ją uzyskać albo spotkać się z odmową dostępu do informacji niezależnie od istnienia lub nieistnienia interesu indywidualnego. Znamienne jest przy tym, że w razie pozytywnego rozpatrzenia wniosku każdy zainteresowany uzyskałby analogiczną treściowo informację. Odmowa udostępnienia informacji, chociaż może być podyktowana ochroną interesu indywidualnego (np. prawa do prywatności), wydawana jest przez organ stojący na straży właściwego realizowania publicznego, zobiektywizowanego prawa do informacji publicznej.

${ }^{45}$ I. Kamińska, M. Rozbicka-Ostrowska, Ustawa o dostępie..., s. 68. Zob. także P. Sitniewski, Ustawa o dostępie do informacji publicznej. Komentarz, Wocław 2011, s. 84.

46 J. Drachal, Prawo do informacji w świetle wykładni funkcjonalnej, w: Sadownictwo administracyjne gwarantem wolności i praw obywatelskich 1980-2005, red. J. Góral, R. Hauser, J. Trzciński, Warszawa 2005, s. 143.

47 K. Tomaszewska, Dostęp do informacji publicznej jako kategoria ochrony..., s. 86.

48 Por. J. Taczkowska-Olszewska, Dostęp do informacji publicznej w polskim systemie prawnym, Warszawa 2014, s. 117.

49 Tamże, s. 87-88. 
Sytuacja może mieć odmienny charakter w przypadku wnioskowania o udostępnienie tzw. przetworzonej informacji publicznej. Zgodnie $\mathrm{z}$ art. 3 ust. 1 pkt 1 ustawy o dostępie do informacji publicznej uzyskanie informacji publicznej przetworzonej jest możliwe $\mathrm{w}$ takim zakresie, $\mathrm{w}$ jakim jest to szczególnie istotne dla interesu publicznego. Występując o tego rodzaju informację, wnioskodawca musi wykazać wystąpienie owego szczególnego rodzaju interesu publicznego ${ }^{50}$. W związku z tym organ rozpatrując sprawę udostępnienia informacji publicznej przetworzonej, musi zbadać wystąpienie tej przesłanki w odniesieniu do konkretnego podmiotu wnioskującego. Rozstrzygnięcia w tego rodzaju sprawach mogą być odmienne w zależności od podmiotu występującego o taką informację ${ }^{51}$. Niemniej nawet $\mathrm{w}$ tego typu przypadkach rozstrzygający, a zatem prawnie relewantny nie jest interes indywidualny (prawny lub faktyczny), a szczególnie istotny, obiektywny interes publiczny.

Mając na względzie powołane wypowiedzi doktryny oraz regulację art. 2 ust. 2 ustawy o dostępie do informacji publicznej precyzującą, że od osoby wykonującej prawo do informacji nie wolno żądać wykazania interesu prawnego lub faktycznego, zasadne jest twierdzenie, że $\mathrm{w}$ postępowaniu o udostępnienie informacji publicznej nie rozstrzyga się o interesie prawnym konkretnego podmiotu - strony w rozumieniu art. 28 K.p.a. ${ }^{52}$ Postępowanie o udostępnienie informacji publicznej zawsze, niezależnie od tego, czy kończy się czynnością materialno-techniczną, czy też decyzją o odmowie lub umorzeniu postępowania, nie ma charakteru postępowania jurysdykcyjnego. Pogląd prezentowany w judykaturze o formalnym charakterze decyzji wydawanej na podstawie art. 16 ust. 1 i 2 ustawy o dostępie do informacji publicznej, która nie rozstrzyga indywidualnej sprawy administracyjnej $\mathrm{w}$ rozumieniu art. 1 pkt 1 K.p.a., zasługuje zatem na pełną aprobatę ${ }^{53}$.

Sprawa odmowy udostępnienia informacji publicznej lub umorzenia postępowania, która powinna być zakończona decyzją wydaną w trybie K.p.a., jest sprawą indywidualną ściśle oznaczonego podmiotu (osoby wnioskującej o informację publiczną) w określonej sprawie, należącej do kompetencji właściwego organu. Jednak sam fakt zaktualizowania się

$50 \mathrm{~W}$ odniesieniu do pojęcia "szczególnie istotnego interesu publicznego" zob. szerzej M. Jabłoński, Udostępnianie przetworzonej informacji publicznej, Wrocław 2015, s. 86-97.

51 Tamże, s. 152-160.

52 Por. M. Jabłoński, Udostępnianie informacji publicznej..., s. 236.

53 Tak w powoływanym wyżej wyroku NSA z dnia 4 listopada 2016 r., I OSK 1372/15, LEX nr 2169772. 
w konkretnym stanie faktycznym sprawy indywidualnej automatycznie nie przesądza o wystąpieniu indywidualnej sprawy administracyjnej o charakterze jurysdykcyjnym ${ }^{54}$. W tego typu postępowaniach kluczowe jest bowiem rozstrzyganie $\mathrm{w}$ formie aktu administracyjnego o interesie prawnym lub obowiązku danego podmiotu i tym samym tworzenie normy indywidualnej oraz konkretnej, kształtującej jego sytuację prawną. W ramach postępowania o udostępnienie informacji publicznej nie dochodzi do wydawania tego typu aktów, a przy wydawaniu decyzji na podstawie art. 16 ust. 2 ustawy o dostępie do informacji publicznej przepisy K.p.a. stosuje się w ograniczonym zakresie.

Zgodnie z art. 16 ust. 2 zd. 1 ustawy o dostępie do informacji publicznej do decyzji o odmowie udostępnienia informacji publicznej oraz umorzeniu postępowania w przypadku określonym w art. 14 ust. 2 tej ustawy stosuje się przepisy K.p.a. Jak wskazuje się w literaturze, zawarte w art. 16 ustawy odesłanie ma $\mathrm{w}$ istocie charakter pozorny i jest niczym innym, jak konsekwencją przyjęcia konstrukcji wyłączenia stosowania pewnych przepisów Kodeksu przez tę ustawę i zastąpienia ich regulacją szczególną ${ }^{55}$. Tak rozumiane, wąskie i stawiające K.p.a. w roli regulacji akcesoryjnej odwołanie stanowi kolejny argument za prawidłowością prezentowanego stanowiska o niejurysdykcyjnym charakterze postępowania o udostępnienie informacji publicznej. Ograniczony zakres oraz wyłączająca natura odwołania z art. 16 ust. 2 ustawy o dostępie do informacji publicznej nakazuje przyjęcie, że omawiana ustawa stanowi lex specialis w odniesieniu do K.p.a. i należy ją uznać za regulację o charakterze dekodyfikacyjnym, czyli regulację procesową obowiązującą obok Kodeksu ${ }^{56}$.

Dodatkowo należy podnieść, że postępowanie w sprawie udostępnienia informacji publicznej, która nie została powszechnie udostępniona, jest postępowaniem wnioskowym. Dlatego też niewłaściwa wydaje się teza, że w przypadku gdy organ uzna za konieczne wydanie decyzji o odmowie dostępu do informacji publicznej, to wówczas wszczyna z urzę$\mathrm{du}$ postępowanie $\mathrm{w}$ tej sprawie ${ }^{57}$. Sam fakt, że organ dąży do wydania

${ }^{54}$ Por. A. Wróbel, w: A. Wróbel, M. Jaśkowska, Kodeks..., s. 67, a także J. Borkowski, w: B. Adamiak, J. Borkowski, Kodeks..., s. 12.

55 Z. Kmieciak, Zarys teorii postępowania administracyjnego, Warszawa 2014, s. 77.

56 J. Zimmermann, Aksjomaty prawa administracyjnego, Warszawa 2013, s. 188.

57 Tezę taką bez szerszej argumentacji prezentuje M. Jaśkowska, Dostęp do informacji publicznych..., s. 60 oraz WSA w Krakowie w wyroku z dnia 21 grudnia 2018 r., II SAB/Kr 215/18, LEX nr 2606887. 
decyzji o odmowie udostępnienia informacji publicznej lub umorzeniu postępowania, nie powoduje przekształcenia charakteru postępowania na wszczynane z urzędu. Postępowanie o udostępnienie informacji publicznej jest bowiem inicjowane żądaniem osoby bez względu na sposób jego zakończenia, a więc zawsze będzie miało cechy postępowania wnioskowego ze wszystkimi konsekwencjami wynikającymi z przepisów omawianej ustawy, a także K.p.a. w odniesieniu do wydawania decyzji administracyjnej. Osoba, która żąda udostępnienia informacji, jest dysponentem postępowania $\mathrm{w}$ tej sprawie, może modyfikować wniosek, zmieniać formę udostępnienia informacji, a także wycofać go w każdym czasie. W sytuacji gdy organ prowadziłby postępowanie $\mathrm{z}$ urzędu, wnioskodawca miałby ograniczone uprawnienia procesowe. Dodatkowo należy podnieść, że art. 16 ustawy o dostępie do informacji publicznej, jak i żadna inna regulacja ustawowa, nie daje podstaw do wszczęcia z urzędu przez organ władzy publicznej lub inny podmiot postępowania w sprawie udostępnienia lub odmowy udostępnienia informacji publicznej. W orzecznictwie sądów administracyjnych zasadnie podkreśla się, że decyzja o odmowie udostępnienia informacji publicznej jest alternatywą dla czynności udostępnienia informacji publicznej i ma charakter odmowy uwzględnienia wniosku inicjującego sprawę udostępnienia informacji publicznej ${ }^{58}$. Skoro zatem podmiot zobowiązany dokonuje czynności udostępnienia informacji publicznej na wniosek, to również postępowanie kończące się odmową udostępnienia informacji toczy się wyłącznie na wniosek, a nie z urzędu.

\section{Zakończenie}

Pomimo występujących w doktrynie prawa oraz orzecznictwie sądów administracyjnych istotnych rozbieżności co do charakteru prawnego postępowania o udostępnienie informacji publicznej, podjęte $\mathrm{w}$ pracy rozważania uzasadniają wniosek, że postępowanie to jest niejurysdykcyjnym postępowaniem pozakodeksowym, w którym dochodzi do urzeczywistnienia wynikającego z art. 61 Konstytucji RP prawa do informacji. Wszczęcie i prowadzenie owego postępowania jest uzależnione od wniosku zainteresowanego podmiotu, który wyznacza zakres postępowania i formę

58 Tak w wyroku NSA z dnia 4 listopada 2016 r., I OSK 1372/15, LEX nr 2169772. 
udostępnienia żądanej informacji. Analizowania ustawa w sposób autonomiczny reguluje postępowanie o udostępnienie informacji publicznej, a odwołanie do K.p.a. ma charakter akcesoryjny i nie wpływa na naturę przedmiotowego postępowania. Brak cech jurysdykcyjności postępowania o udostępnienie informacji publicznej widoczny jest przede wszystkim w tym, że w jego ramach nie rozstrzyga się o indywidualnym interesie prawnym podmiotu żądającego udostępnienia informacji publicznej oraz nie kreuje aktów stosowania prawa w postaci aktów jurysdykcyjnych. Nie bez znaczenia jest również odmienne niż w art. 1 K.p.a. określenie strony podmiotowej postępowania regulowanego w ustawie o dostępie do informacji publicznej.

Przedmiotowa ustawa w odniesieniu do odmowy udostępnienia informacji lub umorzenia postępowania posługuje się wyłącznie formą decyzji administracyjnej uregulowaną szczegółowo w K.p.a. i powszechnie znaną wszystkim podmiotom administrującym. Skorzystanie przez ustawodawcę z formy decyzji administracyjnej we wskazanych przypadkach służy przede wszystkim zagwarantowaniu odpowiednich standardów ochrony prawa do informacji, w tym w szczególności możliwości wszczęcia postępowania odwoławczego oraz sądowoadministracyjnego.

\section{Bibliografia}

Adamiak B., Koncepcja postępowania administracyjnego, w: Prawo procesowe administracyjne, t. 9. System Prawa Administracyjnego, red. R. Hauser, Z. Niewiadomski, A. Wróbel, Warszawa 2010.

Adamiak B., Borkowski J., Kodeks postępowania administracyjnego. Komentarz, Warszawa 2014.

Aleksandrowicz T.R., Komentarz do ustawy o dostępie do informacji publicznej, Warszawa 2008.

Bernaczyk M., Obowiązek bezwnioskowego udostępniania informacji publicznej, Warszawa 2008.

Bernaczyk M., Prawo do informacji publicznej w Polsce i na świecie, Warszawa 2014.

Bidziński M., Chmaj M., Szustakiewicz P., Ustawa o dostępie do informacji publicznej. Komentarz, Warszawa 2015.

Błaś A., Czynności faktyczne organów administracji publicznej, w: Koncepcja systemu prawa administracyjnego, Zjazd Katedr Prawa Administracyjnego i Postępowania 
Administracyjnego, Zakopane 23-27 września 2006 r., red. J. Zimmermann, Warszawa 2007.

Borkowski J., System regulacji prawa procesowego administracyjnego, w: Prawo procesowe administracyjne, t. 9. System Prawa Administracyjnego, red. R. Hauser, Z. Niewiadomski, A. Wróbel, Warszawa 2010.

Drachal J., Prawo do informacji w świetle wykładni funkcjonalnej, w: Sadownictwo administracyjne gwarantem wolności i praw obywatelskich 1980-2005, red. Góral, R. Hauser, J. Trzciński, Warszawa 2005.

Drachal J., Zagadnienia sadowej ochrony prawa do informacji, Zeszyty Naukowe Sądownictwa Administracyjnego 2010, nr 5-6.

Jabłoński M., Udostępnianie informacji publicznej w trybie wnioskowym, Wrocław 2014.

Jabłoński M., Udostępnianie przetworzonej informacji publicznej, Wrocław 2015.

Jaśkowska M., Dostęp do informacji publicznej w orzecznictwie sądów administracyjnych (wybrane problemy), Zeszyty Naukowe Sądownictwa Administracyjnego 2014, nr 1.

Jaśkowska M., Dostęp do informacji publicznej w świetle orzecznictwa Naczelnego Sądu Administracyjnego, Torun 2002.

Kamińska I., Rozbicka-Ostrowska M., Ustawa o dostępie do informacji publicznej. Komentarz, Warszawa 2016.

Kędzierski K., Bezwnioskowy tryb udzielania informacji publicznej, w: Dostęp do informacji publicznej, red. P. Szustakiewicz, Warszawa 2014.

Kędziora R., Ogólne postępowanie administracyjne, Warszawa 2015.

Kłaczyński M., Szuster S., Dostęp do informacji publicznej. Komentarz, Warszawa 2003 [wyd. el. LEX].

Kmieciak Z., Zarys teorii postepowania administracyjnego, Warszawa 2014.

Komentarz do spraw administracyjnych. Wybrane zagadnienia, red. I. Kaminska, J. Matarewicz, M. Rozbicka-Ostrowska, Warszawa 2015 [wyd. el. LEX].

Konstytucja Rzeczypospolitej Polskiej. Komentarz, t. 2, red. L. Garlicki, M. Zubik, wyd. 2, Warszawa 2016 [wyd. el. LEX].

Masternak M., Czynności materialno-techniczne jako prawna forma działania administracji publicznej, Torun 2018.

Piskorz-Ryń A., Zasady udostępniania informacji publicznej, w: Dostęp do informacji publicznej na wniosek w praktyce jednostek samorzadu terytorialnego, red. J. Wyporska-Frankiewicz, Warszawa 2019.

Sitniewski P., Ustawa o dostępie do informacji publicznej. Komentarz, Wocław 2011.

Szustakiewicz P., Orzecznictwo Naczelnego Sadu Administracyjnego z lat 2015-2018 w sprawach dotyczacych informacji publicznej, Przegląd Prawa Publicznego 2019, nr 7-8. 
Szustakiewicz P., Zakres przedmiotowy informacji publicznej. Glosa aprobujaca do wyroku Naczelnego Sadu Administracyjnego z 13 lutego 2019 r. (I OSK 315/17), Samorząd Terytorialny 2019, nr 11.

Tomaszewska K., Dostęp do informacji publicznej jako kategoria ochrony interesu prawnego jednostki w regulacjach prawa administracyjnego, Warszawa 2015.

Wróbel A., Jaśkowska M., Kodeks postępowania administracyjnego. Komentarz, Warszawa 2016.

Zimmermann J., Aksjomaty prawa administracyjnego, Warszawa 2013.

Zimmermann J., Polska jurysdykcja administracyjna, Warszawa 1996.

Zimmermann M., Z rozważań nad postępowaniem jurysdykcyjnym i pojęciem strony w Kodeksie postępowania administracyjnego, w: Księga pamiatkowa ku czci Kamila Stefki, Warszawa-Wrocław 1967.

\section{Streszczenie}

Konstytucja RP w art. 61 gwarantuje każdemu obywatelowi dostęp do informacji publicznej. Tryb udostępniania przedmiotowej informacji został szczegółowo uregulowany w ustawie o dostępie do informacji publicznej. W orzecznictwie sądów administracyjnych oraz doktrynie prawa zarysowały się wyraźnie rozbieżności $\mathrm{w}$ zakresie oceny charakteru prawnego postępowania o udostępnienie informacji publicznej. Zasadniczo zauważalne są dwa stanowiska: pierwsze przyznające temu postępowaniu charakter administracyjnego postępowania jurysdykcyjnego oraz drugie podkreślające charakter niejurysdykcyjny. Przedstawione w artykule rozważania prowadzą do wniosku, że postępowania o udostępnienie informacji publicznej są wszczynane na wniosek podmiotu zainteresowanego niejurysdykcyjnym postępowaniem administracyjnym odrębnym od Kodeksu postępowania administracyjnego.

Słowa kluczowe: dostęp do informacji publicznej, charakter prawny postępowania o udostępnienie informacji publicznej, odmowa udostępnienia informacji publicznej

\section{THE LEGAL NATURE OF THE PROCEEDINGS REGARDING ACCESS TO PUBLIC INFORMATION}

\section{Summary}

In art. 61, the Constitution of the Republic of Poland guarantees every citizen access to public information. The mode of access to the information has been 
regulated in the Act on access to public information. In the jurisprudence of administrative courts and legal doctrine, there were clear discrepancies in the assessment of the legal nature of the proceedings of access to public information. Basically, two statements are noticeable - the first conferring on these proceedings the jurisdictional nature; the second emphasizing the non-jurisdictional character. The considerations presented in the article lead to the conclusion that the procedure of access to public information is initiated at the request of an entity, with non-jurisdictional administrative proceedings separate from the Code of Administrative Proceedings.

Key words: access to public information, legal nature of proceedings of access to public information, refusal of access to public information

\section{О ПРАВОВОЙ ПРИРОДЕ ПРОИЗВОДСТВА ПО ПРЕДОСТАВЛЕНИИ ПУБЛИЧНОЙ ИНФОРМАЦИИ}

\section{Резюме}

Конституция Республики Польша в ст. 61 гарантирует каждому гражданину доступ к публичной информации. Порядок предоставления специальной предметной информации подробно регулирован в Законе о доступе к публичной информации. В судебной практике административных судов и правовой доктрине явно прослеживаются расхождения в оценке правового характера производства по предоставлении публичной информации. В основном, заметны две позиции: первая, которая придает этому производству характер административного юрисдикционного производства, и вторая, которая подчеркивает несудебный характер. Представленный в статье анализ, позволяет сделать вывод, что производства по предоставлении публичной информации возбуждаются по запросу лица, заинтересованного во внесудебном административном производстве отдельным от Административного процессуального кодекса.

Ключевые слова: доступ к публичной информации, правовая природа производства по предоставлении публичной информации, отказ в предоставлении публичной информации 